\title{
Ultra-acute CT perfusion imaging
}

\section{A stroke in the scanner}

田

\section{Figure 1 Clot fragmentation visualized with dynamic CT angiography}

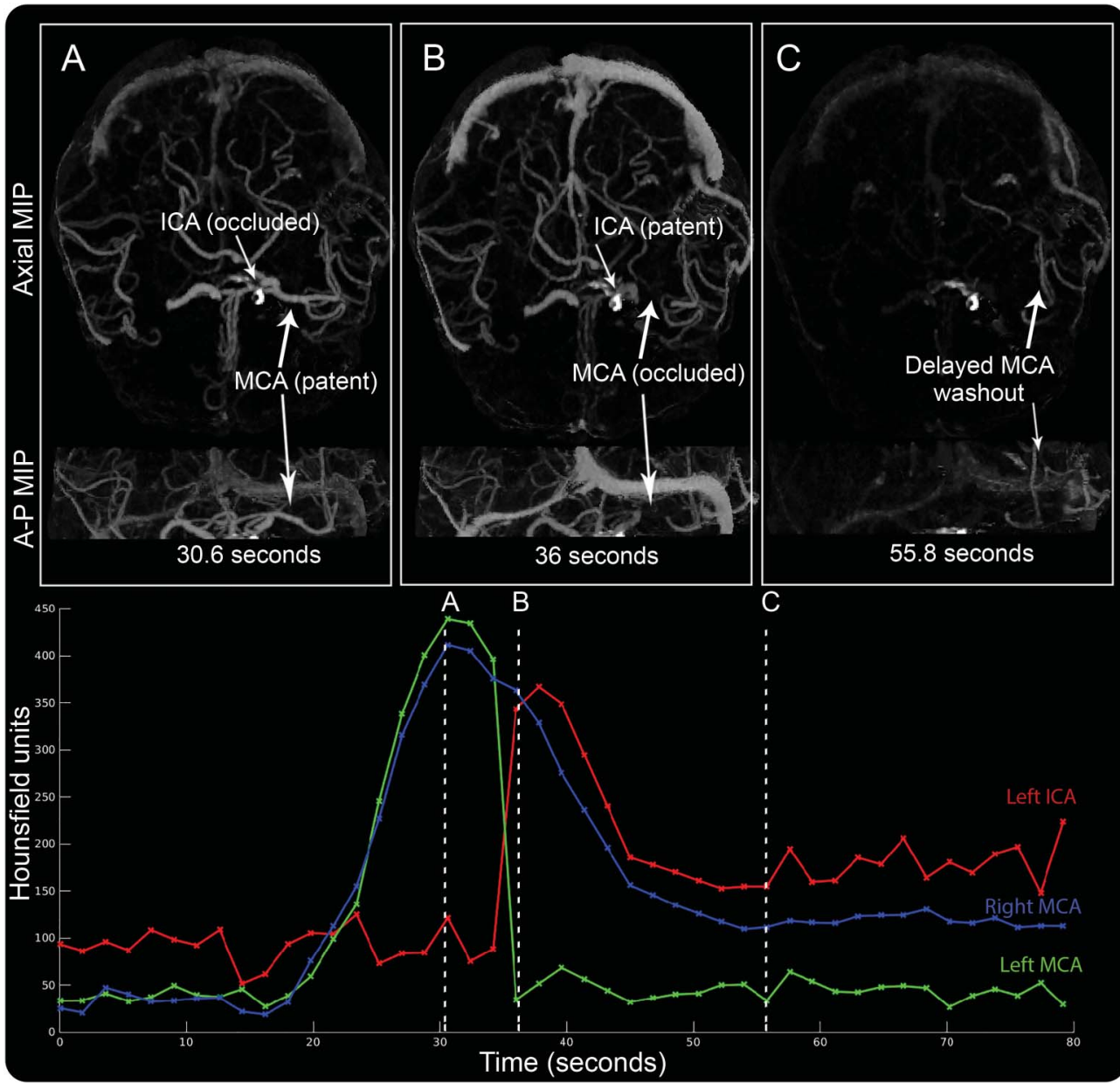

(A) Early phase: left ICA is occluded; the middle, anterior, and fetal posterior cerebral arteries fill through a patent anterior communicating artery. (B) Middle phase: clot dislodged from ICA and fragments obstruct MCA, anterior cerebral artery, and fetal PCA branches. (C) Late phase: stagnation of CT contrast in distal MCA and PCA branches. ICA = internal carotid artery; $\mathrm{MCA}=$ middle cerebral artery; MIP = maximum intensity projection; $\mathrm{PCA}=$ posterior cerebral artery .

Supplemental data at Neurology.org
A stroke patient with a mild right hemiparesis (NIH Stroke Scale score 4) underwent dual-slab CT perfusion (CTP). In the midst of acquiring the lower CTP slab, she became aphasic and developed a dense right hemiparesis (NIH Stroke Scale score 17). Reconstruction of the CTP into a dynamic CT angiogram demonstrates fragmentation of an internal carotid artery thrombus at the time of clinical worsening (figure 1; video on the Neurology ${ }^{\circledR}$ Web site at Neurology.org). The upper CTP slab, acquired 2 minutes later, provides the earliest known view of the hemodynamics of ischemic stroke in humans. It demonstrates total absence of flow to the middle cerebral artery territory during the ultra-acute phase (figure 2). Follow-up imaging demonstrates infarction of this territory.

Soren Christensen, PhD, Chrystal Obi, MD, Greg Albers, MD, Maarten Lansberg, MD, PhD

From the Stanford Stroke Center (S.C., G.A., M.L.) and Stanford Radiology (C.O.), Stanford University, CA. 

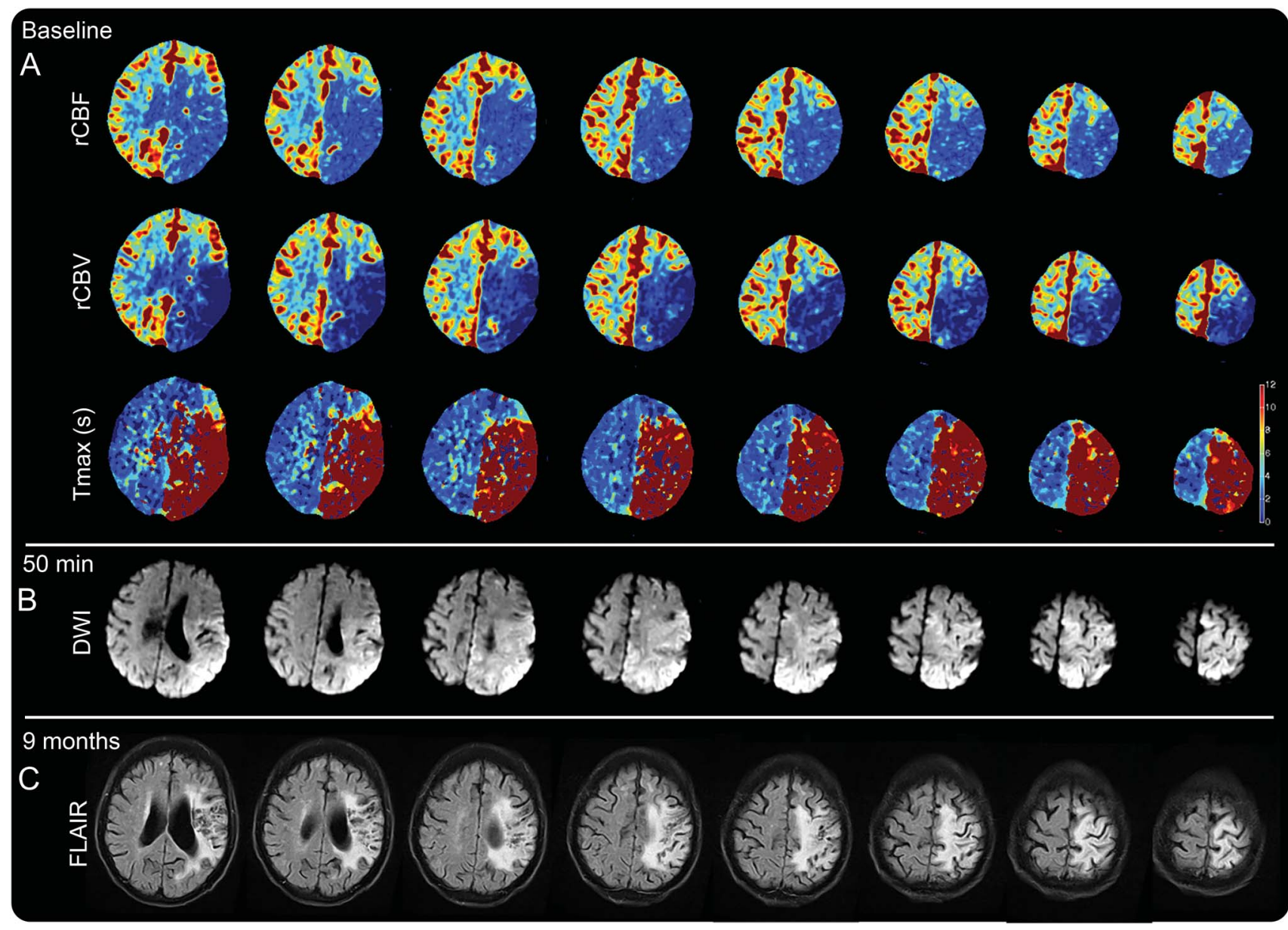

(A) Hyperacute CT perfusion (2 minutes): $\mathrm{CBV}$ and $\mathrm{CBF}$ are severely reduced while Tmax is severely prolonged in the ACA, MCA, and posterior cerebral artery territories. (B) Acute DWI (50 minutes): restricted diffusion of the ACA and MCA territories. (C) FLAIR (9 months): infarction of the territories that demonstrated restricted diffusion. $\mathrm{ACA}=$ anterior cerebral artery; $\mathrm{DWI}=$ diffusion-weighted imaging; $\mathrm{FLAIR}=$ fluid-attenuated inversion recovery; $\mathrm{MCA}=$ middle cerebral artery; rCBF = regional cerebral blood flow; rCBV = regional cerebral blood volume.

Author contributions: Soren Christensen: collected data, analyzed and interpreted data, and drafted the report. Chrystal Obi: saw the patient, interpreted the case, and edited the report. Greg Albers: interpreted the case and edited the report. Maarten Lansberg: interpreted the case and edited the report.

Study funding: No targeted funding reported.

Disclosure: The authors report no disclosures relevant to the manuscript. Go to Neurology.org for full disclosures.

Correspondence to Dr. Christensen: sorenc@stanford.edu

\section{Get Connected. Stay Connected.}

Connect with the American Academy of Neurology's popular social media channels to stay up-todate on the latest news and breakthroughs in neurology, and network with peers and neurology thought leaders. Visit AAN.com/Connect. 


\title{
Neurology
}

\author{
Ultra-acute CT perfusion imaging: A stroke in the scanner \\ Soren Christensen, Chrystal Obi, Greg Albers, et al. \\ Neurology 2015;85;1725-1726 \\ DOI 10.1212/WNL.0000000000002109
}

\section{This information is current as of November 9, 2015}

\section{Updated Information \& \\ Services}

Supplementary Material

Citations

Subspecialty Collections

Permissions \& Licensing

\section{Reprints}

including high resolution figures, can be found at: http://n.neurology.org/content/85/19/1725.full

Supplementary material can be found at: http://n.neurology.org/content/suppl/2015/11/07/WNL.0000000000002 109.DC1

This article has been cited by 1 HighWire-hosted articles: http://n.neurology.org/content/85/19/1725.full\#\#otherarticles

This article, along with others on similar topics, appears in the following collection(s):

\section{All Cerebrovascular disease/Stroke}

http://n.neurology.org/cgi/collection/all_cerebrovascular_disease_strok e

CT

http://n.neurology.org/cgi/collection/ct

Embolism

http://n.neurology.org/cgi/collection/embolism

Infarction

http://n.neurology.org/cgi/collection/infarction

Information about reproducing this article in parts (figures,tables) or in its entirety can be found online at:

http://www.neurology.org/about/about_the_journal\#permissions

Information about ordering reprints can be found online:

http://n.neurology.org/subscribers/advertise

Neurology ${ }^{\circledR}$ is the official journal of the American Academy of Neurology. Published continuously since 1951, it is now a weekly with 48 issues per year. Copyright @ 2015 American Academy of Neurology. All rights reserved. Print ISSN: 0028-3878. Online ISSN: 1526-632X.

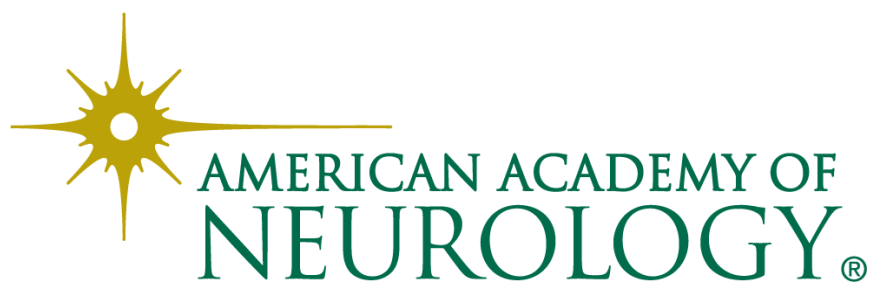

